\title{
Carbon stocks, tree diversity, and the role of organic certification in different cocoa production systems in Alto Beni, Bolivia
}

\author{
Johanna Jacobi $\cdot$ Christian Andres • \\ Monika Schneider • Maria Pillco • \\ Patricia Calizaya $\cdot$ Stephan Rist
}

Received: 17 January 2013 / Accepted: 17 September 2013

(C) Springer Science+Business Media Dordrecht 2013

\begin{abstract}
This study compares aboveground and belowground carbon stocks and tree diversity in different cocoa cultivation systems in Bolivia: monoculture, simple agroforestry, and successional agroforestry, as well as fallow as a control. Since diversified, agroforestry-based cultivation systems are often considered important for sustainable development, we also evaluated the links between carbon stocks and tree diversity, as well as the role of organic certification in transitioning from monoculture to agroforestry. Biomass, tree diversity, and soil physiochemical parameters were sampled in 15 plots measuring $48 \times 48 \mathrm{~m}$. Semi-structured interviews with 52 cocoa farmers were used to evaluate the role of organic certification and farmers' organizations (e.g., cocoa
\end{abstract}

J. Jacobi $(\square) \cdot$ S. Rist

Centre for Development and Environment (CDE),

University of Bern, Hallerstrasse 10, 3012 Bern,

Switzerland

e-mail: johanna.jacobi@cde.unibe.ch

C. Andres - M. Schneider

Research Institute of Organic Agriculture (FiBL),

Ackerstrasse 21, 5070 Frick, Switzerland

M. Pillco

Facultad de Agronomía, Universidad Mayor de San Andrés (UMSA), Héroes del Acre $\mathrm{N}^{\circ} 1850, \mathrm{La} \mathrm{Paz}$,

Bolivia

P. Calizaya

Fundación PIAF - El Ceibo, Sapecho, Alto Beni, La Paz, Bolivia cooperatives) in promoting tree diversity. Total carbon stocks in simple agroforestry systems (128.4 \pm $20 \mathrm{Mg} \mathrm{ha}^{-1}$ ) were similar to those on fallow plots $\left(125.2 \pm 10 \mathrm{Mg} \mathrm{ha}^{-1}\right)$. Successional agroforestry systems had the highest carbon stocks (143.7 \pm $5.3 \mathrm{Mg} \mathrm{ha}^{-1}$ ). Monocultures stored significantly less carbon than all other systems $\left(86.3 \pm 4.0 \mathrm{Mg} \mathrm{ha}^{-1}\right.$, posterior probability $P($ Diff $>0)$ of $0.000-0.006)$. Among shade tree species, Schizolobium amazonicum, Centrolobium ochroxylum, and Anadenanthera sp. accumulated the most biomass. High-value timber species (S. amazonicum, C. ochroxylum, Amburana cearensis, and Swietenia macrophylla) accounted for $22.0 \%$ of shade tree biomass. The Shannon index and tree species richness were highest in successional agroforestry systems. Cocoa plots on certified organic farms displayed significantly higher tree species richness than plots on non-certified farms. Thus, expanding the coverage of organic farmers' organizations may be an effective strategy for fostering transitions from monoculture to agroforestry systems.

Keywords Successional agroforestry Theobroma cacao · Agrobiodiversity · Biomass · Carbon stocks · Organic agriculture $\cdot$ Bolivia

\section{Introduction}

Agriculture in the humid tropics is both highly vulnerable to climate change and contributes to it, 
since the related clearing of rainforests releases high amounts of greenhouse gases (FAO 2011; IPCC 2007). Shortening cycles of slash-and-burn-based cultivation with annual crops in monoculture are changing natural ecosystems, rendering some areas unsuitable for agriculture. Consequently, the agricultural frontier is advancing as land users look for new areas to cultivate. Studies have revealed that deforestation and conversion of forest to agriculture contribute $17.4 \%$ of global greenhouse gas emissions (IPCC 2007). Many observers see agroforestry systems as presenting a promising alternative to common-practice agriculture in the tropics because they can serve as carbon sinks and biodiversity pools and may play a significant role in mitigating or adapting to climate change (Tscharntke et al. 2011; Soto-Pinto et al. 2010; Nair et al. 2009a, b). Similarly, organic agriculture (IFOAM 2005) is perceived as a promising approach (FAO 2011; Leifeld and Fuhrer 2010; MuellerLindenlauf 2009; Niggli et al. 2007). Organic agriculture practices in general and agroforestry in particular are frequently seen as having greater carbon sequestration potential than common-practice agriculture; they are also frequently viewed as making positive contributions to agrobiodiversity and natural biodiversity (FAO 2011). Thus, combining organic certification and practices with agroforestry in the tropics would appear to be a promising strategy for reducing emissions, sequestering carbon, and increasing productivity (Scialabba and Mueller-Lindenlauf 2010; Niggli et al. 2007). A literature review by Nair et al. (2009a) indicated high potential for carbon sequestration in agroforestry systems, especially in the humid tropics. However, agroforestry's capacity for carbon sequestration remains underappreciated and underexploited because of a lack of consistent assessments and comparable data on carbon stocks and carbon cycles (Nair et al. 2009a).

At the same time, there have been many studies on the environmental benefits of agroforestry systems in the tropics (Clough et al. 2011; Tscharntke et al. 2011; Soto-Pinto et al. 2010). By comparison, studies of the effects and challenges of organic agriculture in tropical areas are scarce (FAO 2011; cf. Scialabba and MuellerLindenlauf 2010; Leifeld and Fuhrer 2010; Koepke 2008). One study of organic and conventional shaded and full-sun coffee plantations in Costa Rica and Nicaragua indicated that low-external-input organic cultivation supports agroecosystem services such as biomass inputs and increases soil fertility (Haggar et al. 2011). A meta-analysis of 74 studies comparing organic and non-organic farming systems from all over the world found significantly higher soil organic carbon (SOC) stocks in soils under organic management (Gattinger et al. 2012). Two recent literature reviews-by Mueller-Lindenlauf (2009), FAO (2011) respectively-indicated significantly higher SOC concentrations in organic farming systems when compared with non-organic farming systems. However, the studies assessed by Mueller-Lindenlauf (2009) were all from temperate regions, and FAO (2011) specified that studies from Africa and South America were unavailable, highlighting the lack of data on organic farming in tropical regions.

Many farmers in the region of Alto Beni, Bolivia, have long-standing experience with different forms of agroforestry systems. Still others in the region continue to practice cocoa monocultures. This longrunning diversity of local farming systems makes it possible to compare differently managed cocoa cultivation systems. The present study sought to compare carbon stocks and tree diversity in different cocoa cultivation systems: cocoa monoculture, simple agroforestry systems, and successional agroforestry systems. Fallow plots were also included as a control.

The umbrella organization of cocoa cooperatives El Ceibo active in Alto Beni provides farmers with access to organic certification and related extension services, in an effort to obtain higher cocoa prices, to increase cocoa yields, and to foster more sustainable management of natural resources (Ortiz and Somarriba 2005). However, the question of whether and to what extent such activities have increased the adoption of agroforestry practices among farmers has yet to be answered. As such, the present study also included an analysis of the effect of organic certification and membership in farmers' organizations on the diversity of agroecosystems.

\section{Materials and methods}

The study site: Alto Beni, Bolivia

Cocoa cultivation is one of the most important income sources in the study area, located in Alto Beni, between $15^{\circ} 20^{\prime}$ to $15^{\circ} 55^{\prime} \mathrm{S}$ and $66^{\circ} 55^{\prime}$ to 

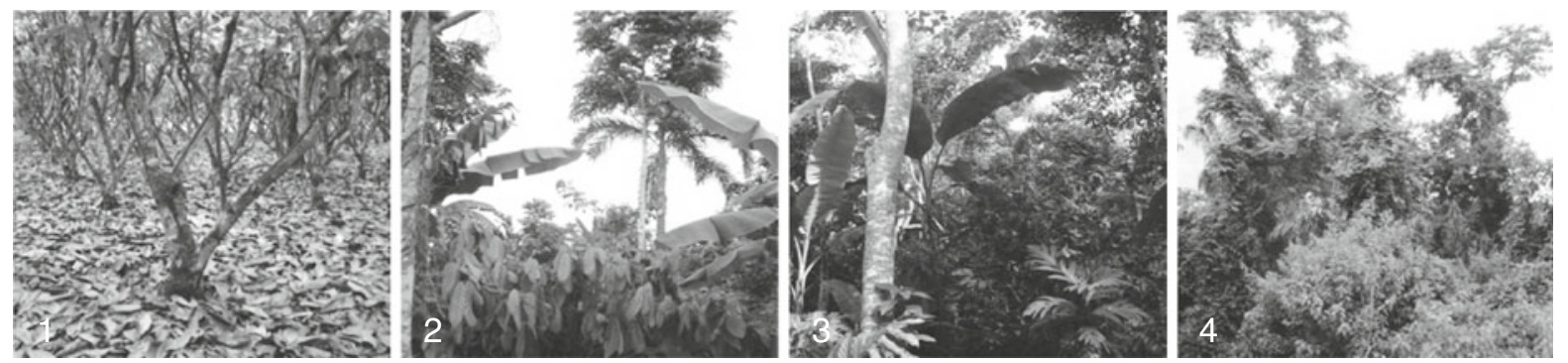

Fig. 1 Different cultivation systems: 1 full-sun monoculture (Mono), 2 simple agroforestry system (AFS), 3 successional agroforestry system (SAFS), 4 fallow (Fallow)

$67^{\circ} 33^{\prime} \mathrm{W}$, in the foothills of the Andes (Ortiz and Somarriba 2005). Classification of land use/land cover in the study area-based on a WorldView-2 image (10 August 2010)—revealed cocoa to be one of the most abundant crops, accounting for up to $25 \%$ of all agricultural land (including fallow land) in the study area (Pinto 2011). The region is composed of valleys featuring wide alluvial terraces and steep hills ranging from 350 to $1,600 \mathrm{~m}$ a.s.l. Annual precipitation varies from 1,300 to $1,500 \mathrm{~mm}$, occurring mostly in the rainy season from November to March (Somarriba and Trujillo 2005). The annual mean temperature is about $26^{\circ} \mathrm{C}$, but minima drop as low as $9{ }^{\circ} \mathrm{C}$ in winter. Soils on the alluvial terrace are mainly classified as Chromic Cambisols and Haplic Lixisols of medium to high fertility; soils on the slopes are primarily classified as Haplic Acrisols and Dystric Cambisols of low fertility (Somarriba and Trujillo 2005). Cocoa is cultivated on the alluvial terraces and slopes as high as $600 \mathrm{~m}$ a.s.l., in plantations measuring around 2.3 ha per family (Somarriba and Trujillo 2005). In the 1960s, Aymaras and Quechuas from the Andean highlands began settling in the region and cultivating cocoa, with support from the Bolivian government. They were given land titles and seedlings, and cocoa was mostly cultivated in monocultures. In the 1980s, agroforestry projects and organic initiatives were launched in the region. By the time data were collected for the present study, $\sim 1,500$ farming families were associated with one of the 49 locally active El Ceibo cocoa cooperatives and/or different farmers' organizations supporting organic certification and cocoa cultivation in the region (El Ceibo 2012, pers. comm.). Nevertheless, half or more of the local cocoa producers in Alto Beni had no or very few shade trees on their cocoa plots (Ortiz and Somarriba 2005).

\section{Different cultivation systems studied}

Biomass, biodiversity, and soil data were sampled in three different cocoa cultivation systems, and in fallow plots (Fig. 1). The systems were: (1) Full-sun cocoa monoculture (hereafter Mono), (2) simple cocoa agroforestry system (hereafter AFS), (3) successional agroforestry system (hereafter SAFS), and (4) agricultural plot under recovery, previously monoculture (hereafter Fallow).

(1) Mono Full-sun monoculture is the most common method of cocoa (Theobroma cacao) cultivation in the study area. Young cocoa plants are planted alongside Musaceae, which initially provide protective shade. Almost no agrochemicals are used in cocoa cultivation in the study area. Cocoa trees are usually pruned once a year, following the main harvest. Cocoa is normally planted at a distance of $4 \times 4 \mathrm{~m}$, resulting in 625 plants per hectare (in monoculture and in agroforestry). Weeding is a constant activity and soil cover crops are uncommon. Individual fruit trees are occasionally scattered around the cocoa plot.

(2) AFS Simple agroforestry systems may feature leguminous shade trees such as Inga spp. and Erythrina poeppigiana; associated fruit trees such as Rheedia spp., Nephelium lappaceum, Theobroma grandiflorum, and Persea americana; and timber trees such as Swietenia macrophylla, Hymenaea courbaril, Centrolobium ochroxylum, Cedrela odorata, and Amburana cearensis. Cocoa trees and shade trees are 
usually pruned once a year to induce flowering of cocoa and to regulate shade. The need for weeding depends on shade intensity and whether soil cover crops are present.

(3) SAFS Successional agroforestry systems feature multi-purpose agroforestry shade trees, natural regeneration trees, and many crops. They are based on understanding and application of natural succession dynamics. The plant species occurring in the process of natural succession may be grouped as pioneers, secondary or primary forest species, depending on their life cycle. These species can be replaced by similarly grouped agricultural crops. The aim is to form a composition of species in which all stories (spatial) and all phases (temporal) are occupied by specific species, maximizing density and diversity. In SAFS in which cocoa is the main crop, the process is often initiated with maize and rice in combination with manioc (Manihot esculenta) and pigeon pea (Cajanus cajan), quickly followed by banana (Musaceae) and papaya (Carica papaya), then pineapple (Ananas comosus) and Inga sp., which provide shade that enables more slowly growing primary forest species such as cocoa and $S$. macrophylla to thrive. The latter species will dominate the system after $10-15$ years. The overall process benefits farmers by enabling them to obtain harvests from the first year on thanks to crops in the pioneer and secondary forest species categories. Furthermore, the system's high diversity provides a number of environmental services, such as soil preservation and regeneration (Vieira et al. 2009), accumulation of organic matter, and pest control (Milz 2010). Management of SAFS is knowledge and labor intensive. It requires regular pruning and selective weeding that depend greatly on farmers' understanding of the system and its underlying dynamics. Pest and weed pressures are considered indicators of incorrect management. Optimal implementation of SAFS can result in high yields from a range of crops with minimal use of external inputs (Schulz 2011; Milz 2010; Vieira et al. 2009; Yana and Weinert 2001; Schulz et al. 1994).

(4) Fallow These are plots featuring naturally regenerating pioneer vegetation and secondary forest, occasionally complemented by leguminous trees. Farming families sometimes fetch firewood and harvest wild fruit or medicinal plants from such plots. Fallow was included in this analysis to compare the data from Mono, AFS, and SAFS with data from plots left to naturally regenerate (for soil recovery), and because fallow is an integral part of the local land use cycle.

The previous land use of most SAFS and AFS plots studied was fallow (followed by 1-2 years of rice, Oryza sativa, and/or corn, Zea mays, before planting cocoa) or cocoa monoculture. Mono plots were installed in riparian vegetation or monocultures of other crops. Previous land use of fallow plots was cocoa, citrus, or papaya monocultures (Table 1). There were no input-intensive organic or conventional cultivation systems as described by Noponen et al. (2012). Cocoa pod husks from harvested cocoa beans were the only fertilizer used (applied in all cocoa systems). Thus, all of the cocoa cultivation systems in the study area could be considered low- or even zeroexternal-input systems.

Farm selection, plot design, and sampling

Representative cocoa farms for the systems SAFS, AFS, and Mono were selected in collaboration with local agricultural consultants, taking into account environmental conditions and plantation age (Table 1). The farms were distributed between three spatial clusters (population centers) along the river Alto Beni (Fig. 2). Organic certification was not a selection criterion. Certification was mainly organized by cooperatives belonging to El Ceibo. Cocoa farms obtained organic certification after a three-year transition period, and were inspected annually. Since import countries' organic certification standards do not explicitly require cultivation of cocoa in agroforestry systems, there are also cocoa monocultures in Alto Beni that are certified organic. However, the Monos in our study were not certified. By contrast, all SAFS and all but one AFS in the present study were certified organic.

Sampling plots measuring $48 \times 48 \mathrm{~m}$ (based on the cocoa planting distance of $4 \times 4 \mathrm{~m}$ ) were installed on every farm $(n=12)$; the sampling plots were further divided into four sub-plots measuring $24 \times 24 \mathrm{~m}$ (ICRAF 2005; Pearson et al. 2005). Four sampling 
Table 1 Location, physical, and environmental conditions of the sampling plots; Mono cocoa monoculture, AFS simple agroforestry system, SAFS successional agroforestry system

\begin{tabular}{|c|c|c|c|c|c|c|c|c|}
\hline & Coordinates & $\begin{array}{l}\text { Elevation } \\
\text { (m.a.s.l.) }\end{array}$ & $\begin{array}{l}\text { Slope } \\
\left({ }^{\circ}\right)\end{array}$ & $\begin{array}{l}\text { Distance to } \\
\text { river }(\mathrm{km})\end{array}$ & $\begin{array}{l}\text { Mean annual } \\
\text { temp. }\left({ }^{\circ} \mathrm{C}\right)^{\mathrm{a}}\end{array}$ & $\begin{array}{l}\text { Mean annual } \\
\text { precipitation } \\
(\mathrm{mm})^{\mathrm{a}}\end{array}$ & $\begin{array}{l}\text { Age of } \\
\text { plantation }(y)\end{array}$ & Previous land use \\
\hline Mono 1 & $\begin{array}{l}15^{\circ} 26^{\prime} 31^{\prime \prime} \mathrm{S} \\
67^{\circ} 28^{\prime} 11^{\prime \prime} \mathrm{W}\end{array}$ & 360 & 0 & 0.4 & N. a. & 1,293 & 5 & Riverine vegetation \\
\hline Mono 2 & $\begin{array}{l}15^{\circ} 40^{\prime} 2.9^{\prime \prime} \mathrm{S} \\
67^{\circ} 10^{\prime} 20^{\prime \prime} \mathrm{W}\end{array}$ & 465 & 1.5 & 2.5 & 24.9 & 1,540 & 8 & Plantain monoculture \\
\hline Mono 3 & $\begin{array}{l}15^{\circ} 45^{\prime} 34^{\prime \prime} \mathrm{S} \\
67^{\circ} 3^{\prime} 1^{\prime \prime} \mathrm{W}\end{array}$ & 493 & 0 & 0.6 & 24.6 & 1,372 & 5 & Papaya monoculture \\
\hline Mono 4 & $\begin{array}{l}15^{\circ} 48^{\prime} 43^{\prime \prime} \mathrm{S} \\
66^{\circ} 59^{\prime} 2^{\prime \prime} \mathrm{W}\end{array}$ & 515 & 0 & 1.6 & 24.6 & 1,372 & 20 & Riverine vegetation \\
\hline AFS 1 & $\begin{array}{l}15^{\circ} 29^{\prime} 12^{\prime \prime} \mathrm{S} \\
67^{\circ} 24^{\prime} 14^{\prime \prime} \mathrm{W}\end{array}$ & 476 & 0 & 2.3 & N. a. & 1,293 & 17 & Cocoa monoculture \\
\hline AFS 2 & $\begin{array}{l}15^{\circ} 38^{\prime} 7^{\prime \prime} \mathrm{S} \\
67^{\circ} 12^{\prime} 7^{\prime \prime} \mathrm{W}\end{array}$ & 448 & 1.5 & 0.9 & 24.9 & 1,540 & 8 & Fallow \\
\hline AFS 3 & $\begin{array}{l}15^{\circ} 45^{\prime} 8^{\prime \prime} \mathrm{S} \\
67^{\circ} 1^{\prime} 41^{\prime \prime} \mathrm{W}\end{array}$ & 483 & 0 & 0.7 & 24.6 & 1,372 & 17 & Fallow \\
\hline AFS 4 & $\begin{array}{l}15^{\circ} 30^{\prime} 44^{\prime \prime} \mathrm{S} \\
67^{\circ} 25^{\prime} 57^{\prime \prime} \mathrm{W}\end{array}$ & 365 & 0 & 0.3 & N. a. & 1,293 & 10 & N. a. \\
\hline SAFS 1 & $\begin{array}{l}15^{\circ} 29^{\prime} 56^{\prime \prime} \mathrm{S} \\
67^{\circ} 24^{\prime} 34^{\prime \prime} \mathrm{W}\end{array}$ & 510 & 0 & 1.7 & N. a. & 1,293 & 16 & Fallow \\
\hline SAFS 2 & $\begin{array}{l}15^{\circ} 37^{\prime} 20^{\prime \prime} \mathrm{S} \\
67^{\circ} 10^{\prime} 7^{\prime \prime} \mathrm{W}\end{array}$ & 441 & 2 & 1.6 & 24.9 & 1,540 & 13 & Cocoa monoculture \\
\hline SAFS 3 & $\begin{array}{l}15^{\circ} 44^{\prime} 20^{\prime \prime} \mathrm{S} \\
67^{\circ} 5^{\prime} 59^{\prime \prime} \mathrm{W}\end{array}$ & 503 & 0.5 & 2.3 & 24.6 & 1,372 & 14 & Pasture \\
\hline SAFS 4 & $\begin{array}{l}15^{\circ} 45^{\prime} 50^{\prime \prime} \mathrm{S} \\
67^{\circ} 0^{\prime} 7^{\prime \prime} \mathrm{W}\end{array}$ & 510 & 0 & 0.8 & 24.6 & 1,372 & 14 & N. a. \\
\hline Fallow 1 & $\begin{array}{l}15^{\circ} 26^{\prime} 41^{\prime \prime} \mathrm{S} \\
67^{\circ} 28^{\prime} 4^{\prime \prime} \mathrm{W}\end{array}$ & 360 & 0 & 0.6 & N. a. & 1,293 & 15 & Papaya monoculture \\
\hline Fallow 2 & $\begin{array}{l}15^{\circ} 38^{\prime} 6^{\prime \prime} \mathrm{S} \\
67^{\circ} 12^{\prime} 7^{\prime \prime} \mathrm{W}\end{array}$ & 446 & 0 & 2 & 24.6 & 1,540 & 8 & Cocoa monoculture \\
\hline Fallow 3 & $\begin{array}{l}15^{\circ} 44^{\prime} 9^{\prime \prime} \mathrm{S} \\
67^{\circ} 5^{\prime} 5^{\prime \prime} \mathrm{W}\end{array}$ & 512 & 0 & 2.1 & 24.9 & 1,372 & 15 & Cocoa monoculture \\
\hline
\end{tabular}

a Source Elbers (2002)

plots were installed per cultivation system-SAFS, AFS, and Mono. Additionally, one fallow sampling plot was installed per cluster on a cocoa farm where one SAFS, AFS, or Mono sampling plot had already been installed. This resulted in three fallow sampling plots in total. One or two replications of each cultivation system were sampled in each spatial cluster, depending on availability; this resulted in four replications per cultivation system in total (Fig. 2). All data were sampled between April and November 2010 (dryer season).

\section{Biomass and carbon assessment}

We assessed aboveground biomass (AGB) and belowground biomass (BGB) using both destructive and non-destructive methods. To determine AGB, we measured the following components: tree diameter at 


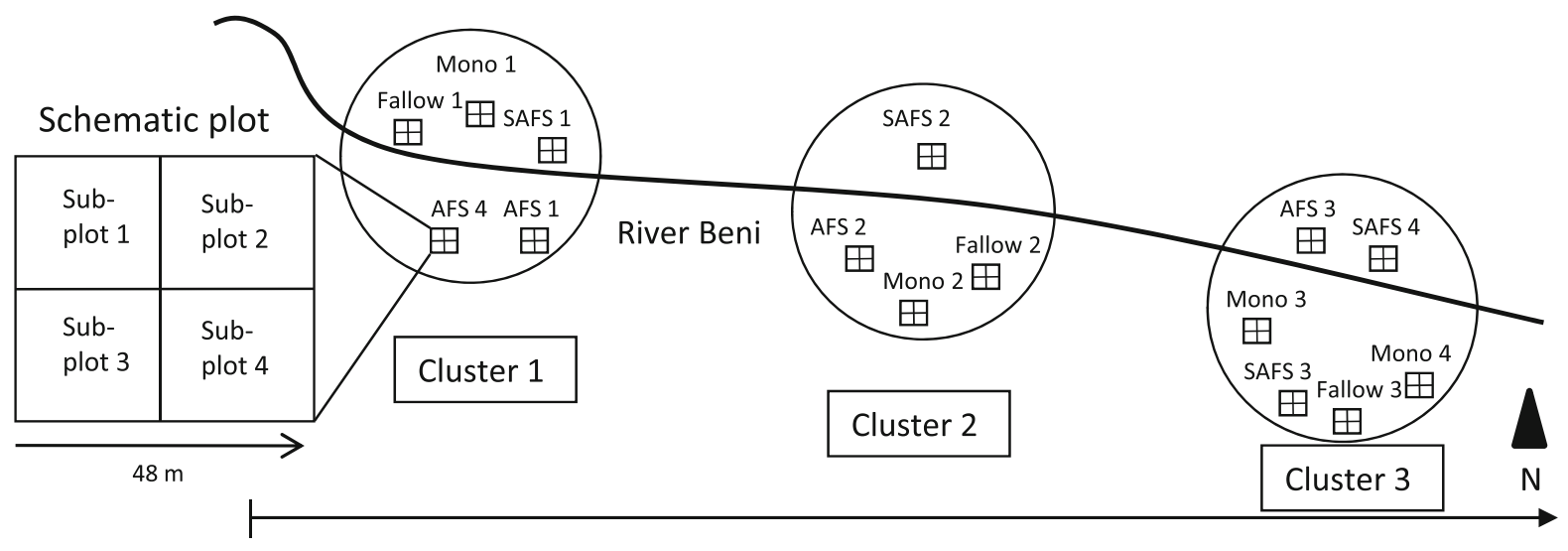

$60 \mathrm{Km}$

Fig. 2 Schematic map of the research design

Table 2 Allometric equations used for biomass estimation

\begin{tabular}{|c|c|c|c|}
\hline & Formula & $\mathrm{R}^{2}$ & Source \\
\hline Shade trees & $A G B=0.0509 * \rho * D^{2} * H$ & 0.96 & $\begin{array}{l}\text { Chave } \\
\text { et al. } \\
(2005)\end{array}$ \\
\hline Palm trees & $A G B=10.0+6.4 * H$ & 0.96 & $\begin{array}{l}\text { Brown } \\
\text { (1997) }\end{array}$ \\
\hline $\begin{array}{c}\text { Theobroma } \\
\text { cacao }\end{array}$ & $A G B=10^{\left(-1.625+2.63 * \log \left(D_{30}\right)\right)}$ & 0.98 & $\begin{array}{c}\text { Andrade } \\
\text { et al. } \\
\text { (2008) }\end{array}$ \\
\hline $\begin{array}{l}\text { Coffea } \\
\quad \text { arabica }\end{array}$ & $A G B=10^{\left(-1.18+1.19 * \log \left(D_{15}\right)\right)}$ & 0.93 & $\begin{array}{c}\text { Andrade } \\
\text { et al. } \\
\text { (2008) }\end{array}$ \\
\hline Musaceae & $A G B=0.030 * D B H^{2.13}$ & 0.99 & $\begin{array}{l}\text { Pearson } \\
\text { et al. } \\
(2005)\end{array}$ \\
\hline
\end{tabular}

$A G B$ aboveground biomass per kg dry matter, $\rho$ wood density in $\mathrm{g} \mathrm{cm}^{-3}, D$ diameter in $\mathrm{cm}, H$ height in $\mathrm{m}$

breast height (130 cm, hereafter DBH); and tree height (of trees with $\mathrm{DBH} \geq 5 \mathrm{~cm}$ ) using a clinometer (Chave et al. 2005; Santos et al. 2004). The species was categorized and annotated. The formula we used to calculate the biomass of shade trees (moist forest stands, Chave et al. 2005) is more conservative than the formula used by Brown (1997) and recommended by UNFCCC (2009). To calculate biomass using allometric formulas (Table 2), we subdivided trees and crops into different classes: shade trees, palm trees, cocoa, coffee (Coffea arabica), and banana/ plantains (Musaceae).
Depending on the tree/crop, we measured stem diameters at the following heights: cocoa at a height of $30 \mathrm{~cm}$ (Andrade et al. 2008); coffee at a height of $15 \mathrm{~cm}$ (Andrade et al. 2008; Segura et al. 2006); and shade trees, palm trees, and Musaceae at a height of $130 \mathrm{~cm}$.

Wood densities were obtained from the list by Brown (1997) as well as the World Agroforestry Centre's Wood Density Database (ICRAF 2011). If a species was not listed, we used a mean wood density of $0.6 \mathrm{~g} \mathrm{~cm}^{-3}$ as suggested by Brown (1997).

Litter, as well as herbs and shrubs with $\mathrm{DBH}<5 \mathrm{~cm}$ were sampled five times per sampling plot, from a square measuring $50 \times 50 \mathrm{~cm}$ (Andrade and Ibrahim 2003; Hairiah et al. 2001), and air-dried to constant weight.

We assessed biomass from dead wood using the line-intersect method (Pearson et al. 2005). The dry weight of dead wood was calculated using the following formula:

$W=\left(S \frac{\pi^{2}}{8 L}\right) \sum d^{2}$

where $\mathrm{W}=$ dry weight in $\mathrm{g} \mathrm{cm}^{-3}, \mathrm{~S}=$ wood density, and $\mathrm{L}=$ length of the sample line. Twigs and dead wood with diameter $\geq 0.5 \mathrm{~cm}$ were thus not included in the litter fraction. For dead wood density, we assumed a default value of $0.5 \mathrm{~g} \mathrm{~cm}^{-3}$ (Hairiah et al. 2001).

The biomass from coarse roots was calculated using the formula of Cairns et al. (1997), also recommended by Pearson et al. (2005): 
BGB from coarse roots $=\exp ^{(-1.085+0.926 * \ln (\mathrm{AGB}))}$

We sampled fine roots $\leq 5 \mathrm{~mm}$ at three depths $(0-10,10-20$, and $20-30 \mathrm{~cm})$ twice at the center of each sub-plot (Roncal-García et al. 2008). We washed and air-dried the samples to constant weight at the Experimental Station of the Faculty of Agronomy, University of La Paz (UMSA). To calculate carbon stocks from total biomass (AGB + BGB), we applied the factor 0.5 (IPCC 2003).

To assess SOC and the soil parameters clay content, $\mathrm{pH}$, total $N$, available $P$, exchangeable $\mathrm{K}$, and CEC, soil was sampled at two soil depths (0-25 and $25-50 \mathrm{~cm}$ ) using a soil auger every $5 \mathrm{~m}$ in a grid. We mixed the samples at the sub-plot level, so that two soil samples-one topsoil and one subsoil samplewere obtained per sub-plot, resulting in eight soil samples (four topsoil; four subsoil) per replication/ farm (cf. Schroth and Sinclair 2003). The bulk density of topsoil and subsoil was sampled with metal cylinders at the center of each sub-plot, according to the method described by Schroth and Sinclair (2003), resulting in eight bulk-density samples (four topsoil; four subsoil) per replication/farm. SOC was determined following the Walkley-Black method as described by van Reeuwijk (2002). All soil parameters were determined according to ISRIC standards (van Reeuwijk 2002). The depth of the Ah horizon was also measured at the center of each sub-plot.

When comparing carbon stocks calculated from carbon concentrations in different land use systems, differing soil mass at the same sampling depth-due to differing bulk density—can lead to errors (Nair 2011; Don et al. 2011). Without soil mass corrections, the influence of different land use systems on SOC is likely to be underestimated (Don et al. 2011; Schroth and Sinclair 2003). Thus, in line with de Moraes et al. (1996), we calculated SOC with an equivalent soil mass (mean soil mass of all sub-plots), carbon concentration in $\%$, bulk density in $\mathrm{g} \mathrm{cm}^{-3}$, and sampling depth in $\mathrm{cm}$.

Belowground carbon was then calculated as the sum of SOC and biomass from coarse roots $* 0.5$ and fine roots $* 0.5$ (IPCC 2003).

\section{Quantification of tree and crop diversity}

Tree species were identified with the help of staff from El Ceibo's forest seed bank. To identify and compare
Table 3 Coefficients of the first three PCs based on age, location, and soil fertility parameters of 15 cocoa farms in Alto Beni, Bolivia

\begin{tabular}{lccc}
\hline Parameters & $\begin{array}{l}\text { PC 1 } \\
\text { Eigenvectors }\end{array}$ & $\begin{array}{l}\text { PC 2 } \\
\text { Eigenvectors }\end{array}$ & $\begin{array}{l}\text { PC 3 } \\
\text { Eigenvectors }\end{array}$ \\
\hline Age & -0.392 & 0.647 & 0.346 \\
Distance to river & 0.303 & 0.768 & -0.263 \\
$\begin{array}{l}\text { Depth Ah } \\
\text { horizon }\end{array}$ & & & 0.919 \\
Clay content & 0.934 & 0.153 & \\
pH & 0.205 & -0.648 & \\
Total $N$ & 0.736 & -0.142 & 0.339 \\
Available $P$ & 0.666 & -0.315 & -0.355 \\
Exchangeable K & 0.926 & -0.152 & \\
CEC & 0.948 & -0.131 & -0.108 \\
Eigenvalue & 4.08 & 1.48 & 1.24 \\
Cumulative & 43.3 & 61.3 & 75.6 \\
$\quad$ variance $(\%)$ & & & \\
\hline
\end{tabular}

the diversity of trees and crops in the different cultivation systems, we calculated the Shannon diversity index $\left(\mathrm{H}_{\mathrm{S}}\right)$ (ICRAF 2005; Shannon and Weaver 1949):

$H_{S}=-\sum_{i=1}^{S} p_{i} \ln p_{i}$

where $\mathrm{S}=$ number of categories in a habitat, $\mathrm{p}_{\mathrm{i}}=$ share from one category in the total number of categories. The maximum possible value $H_{\max }\left(-\ln \frac{1}{i}\right)$ and evenness $\left(H_{S} / H_{\max }\right)$ are also displayed to give an impression of the distribution of species.

Organic certification and affiliation with a farmers' organization

To investigate the role of organic certification and the influence of local farmers' organizations - such as cooperatives - on the type of cocoa cultivation system practiced by farmers, we conducted 52 semi-structured interviews. We interviewed 30 certified-organic cocoa producers and 22 non-certified cocoa producers. They were asked questions such as the number of tree species in their main cocoa plots and what they perceived as key potentials and constraints of the three different cocoa cultivation systems. Producers were also asked about their motivation to join a cooperative or other farmers' organization, and the implications of membership for organic certification. The information from the 
interviews was analyzed qualitatively following Patton (2002).

Statistical analysis

To explore differences in age, location, and soil fertility between the farms, we performed a principal component analysis (PCA). The PCA included the following parameters: age of plantation; distance to river; depth of Ah horizon; clay content; $\mathrm{pH}$; total $N$; available $P$; exchangeable $\mathrm{K}$; and CEC. The resulting principal components (PC) were checked for their eigenvalues, and the PCA was recomputed using only PC with eigenvalues $>1$ (first three PC). Together, these three PC accounted for $75.6 \%$ of the variance in the data across all farms. We calculated the PC using the library "psych" (Revelle 2012) and rotated the axis with the varimax function from the library "GPArotation" (Bernaards and Jennrich 2012). The PCA results are shown in Table 3.

The data at sub-plot level were analyzed with linear mixed-effect models. We began with a model with cultivation system, pc1, pc2, and pc3 defined as fixed effects, and plot and cluster as random intercepts. For each dependent variable (total biomass, SOC stocks, total $\mathrm{C}$, aboveground $\mathrm{C}$, belowground $\mathrm{C}$, and fine roots), we then compiled the best model via backward selection of model parameters using likelihood-ratio tests including only main effects with $P<0.05$. We checked model assumptions graphically (normal Q-Q, Tukey-Anscombe, and Jitter plots). To compare the means of the different cultivation systems, we used a multilevel-modeling approach (Gelman et al. 2012). We defined cultivation system as a random factor in the best model, and the shrinked group mean estimate was used to do post hoc comparisons. Using the package "arm", we simulated $(n=4,000)$ a random sample of the joint posterior distribution of the model parameters and calculated the differences between the group means; this generates a random sample from the posterior distribution of the between-group differences. From these posterior distributions, we extracted the probabilities of the hypothesis that the difference is bigger than zero $P($ Diff $>0)$. We defined a difference to be significant if $P($ Diff $>0)<0.025$ or $>0.975$ (equal to $P<0.05$ in general linear models).

The effect of organic certification and membership in farmers' organizations on tree diversity in cocoa plots was tested using Kruskal-Wallis rank-sum tests. Correlation 
between Ah horizon and bulk density was tested using Pearson's product-moment correlation. All statistical computing was done in $\mathrm{R}$, version 2.15.2 (R Development Core Team 2012).

\section{Results}

Biomass and carbon assessment

Total biomass ranged from $62.2 \pm 12 \mathrm{Mg} \mathrm{ha}^{-1}$ in Mono to $186.8 \pm 10 \mathrm{Mg} \mathrm{ha}^{-1}$ in SAFS. Post-hoc tests showed that the system Mono was significantly different from all other systems (Posterior probability $P($ Diff $>0)=0.000$ or 1.000 for all). SAFS was also significantly different from all other systems (posterior probability $P($ Diff $>0)=0.000$ or 1.000 for all). AFS and Fallow did not differ significantly from each other, displaying total biomass between Mono and SAFS (Posterior probability $P($ Diff $>0)=0.412$, Table 4).

Fine roots ranged from $4.9 \pm 0.9 \mathrm{Mg} \mathrm{ha}^{-1}$ in Mono to $10.6 \pm 1.2 \mathrm{Mg} \mathrm{ha}^{-1}$ in SAFS. Post-hoc tests showed that Mono was significantly different from all other systems (posterior probability $P($ Diff $>0)$ between 0.003 and 0.000 ). Fallow did not differ significantly from AFS $(P($ Diff $>0)=0.074)$ and was almost significantly different from SAFS $(P($ Diff $>0)=$ 0.973). AFS and SAFS were not significantly different from each other $(P($ Diff $>0)=0.687$, Table 4$)$.

SOC stocks ranged from $50.8 \pm 2.7 \mathrm{Mg} \mathrm{ha}^{-1}$ in SAFS to $64.8 \pm 9.5 \mathrm{Mg} \mathrm{ha}^{-1}$ in Fallow, and accounted for $47.7 \%$ of total carbon stocks. In SAFS, SOC had a share of $35.5 \%$ of total carbon; in AFS, its share was $46.6 \%$; in Fallow, its share was $51.8 \%$; and in Mono, SOC's share was $64.0 \%$ of total carbon. Post-hoc tests showed that no system differed significantly from the others $(P($ Diff $>0)$ between 0.498 and 0.596, Table 4).

Total $C$ ranged from $86.3 \pm 4.0 \mathrm{Mg} \mathrm{ha}^{-1}$ in Mono to $143.7 \pm 5.3 \mathrm{Mg} \mathrm{ha}^{-1}$ in SAFS (Table 4). Figure 3 shows aboveground carbon stocks according to components, indicating that shade trees were the main component of aboveground-biomass-based carbon stocks across all systems (constituting $50.3 \%$ of aboveground carbon stocks and $19.7 \%$ of total carbon stocks). Figure 4 shows belowground carbon stocks, indicating that SOC stocks were the main component of total carbon stocks across all systems. Post-hoc tests 


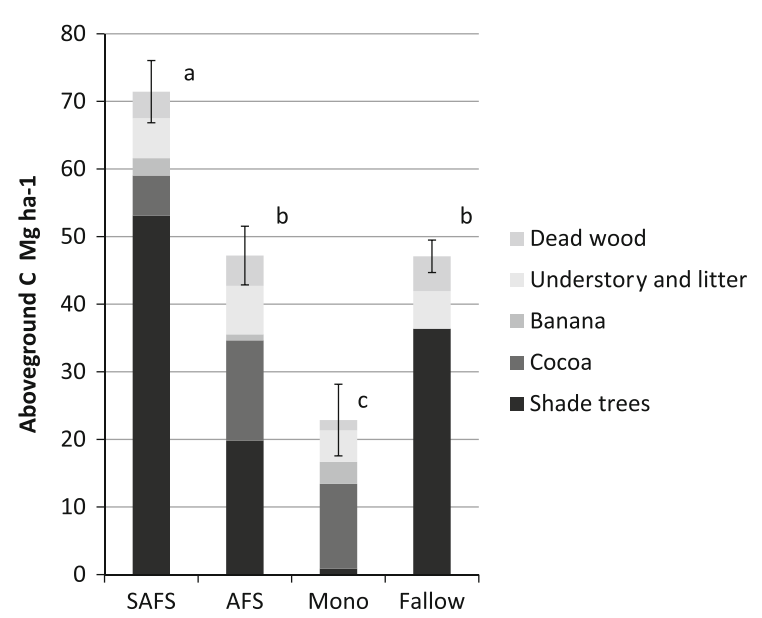

Fig. 3 Aboveground carbon stocks according to components with standard error of means; SAFS successional agroforestry system, AFS simple agroforestry system, Mono cocoa monoculture; shade trees include palm trees; $a, b, c$ No significant difference for bars sharing the same letter

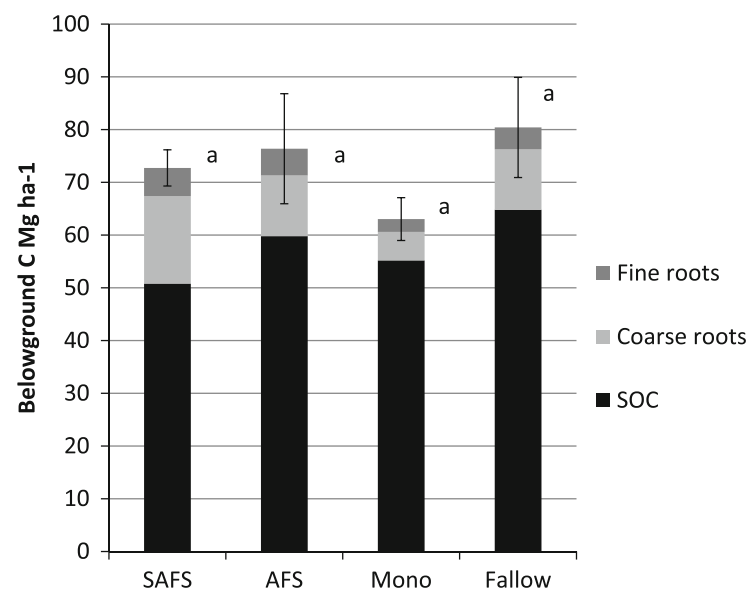

Fig. 4 Belowground carbon stocks $(0-50 \mathrm{~cm})$ according to components with standard error of means; SAFS successional agroforestry system, AFS simple agroforestry system, Mono cocoa monoculture; $a$ No significant difference for bars sharing the same letter

for total C showed that Mono was significantly different from AFS (posterior probability $P($ Diff $>0)=0.002)$, Fallow (posterior probability $P($ Diff $>0)=0.006$ ), and SAFS (posterior probability $P($ Diff $>0)=1.000)$. The remaining systems did not differ significantly from each other $(P($ Diff $>0)$ between 0.417 and 0.923 ). Comparison of aboveground carbon stocks alone revealed all systems to be significantly different from each other except Fallow and AFS (Fig. 3, posterior probability $P($ Diff $>0)=$ 0.000 or 1.000 for all). In regards to belowground carbon stocks alone, post hoc tests showed that no system differed significantly from the others $(P($ Diff $>0)$ between 0.217 and 0.644).

Depth of Ah horizon in SAFS and AFS was higher than in Fallow and in Mono (Table 5). Ah horizon was negatively correlated with bulk density $\left(r^{2}=-0.64\right.$, $P<0.05$, Pearson's product-moment correlation).

\section{Diversity of trees and crops}

Altogether, 105 tree species belonging to 38 families were identified in the sampling plots, 96 species in cocoa agroforestry systems (AFS and SAFS), and four species in Mono. Eight species could not be identified (two in SAFS, one in AFS, and five in Fallow). The richest family was Fabaceae with 18 species, followed by Rutaceae (eight species), Moraceae (six species), and Bombacaceae (five species). The majority of plant families (27) were only represented by one or two species.

Stem density of woody perennials without cocoa was highest in Fallow $(1,374 \pm 437)$ and more than double in SAFS $(699 \pm 114)$ compared to AFS $(296 \pm 71.2$, Table 5). The Shannon index for SAFS $\left(\mathrm{HS}=2.3 \pm 0.1, \quad \mathrm{H}_{\max }=4.3, \quad\right.$ Evenness $\left.=0.53\right)$ was higher than all other systems, including Fallow $\left(\mathrm{HS}=2.0 \pm 0.5, \mathrm{H}_{\max }=3.85\right.$, Evenness $=0.52$ ). However, Fallow displayed a higher Shannon index than AFS ( $\mathrm{HS}=1.7 \pm 0.2, \mathrm{H}_{\max }=3.99$, Evenness $=0.42$ ). As expected, Mono displayed the lowest Shannon index $\left(\mathrm{HS}=0.3 \pm 0.2, \quad \mathrm{H}_{\max }=1.38\right.$, Evenness $=0.25$ ).

The most abundant shade tree species were Leucaena leucocephala ( $\mathrm{N}$-fixing species, used for improved fallows), Piper angustifolium (natural succession), A. cearensis (timber), Attalea phalerata (natural succession, fruit, and other plant material used, e.g., for construction or medicinal purposes), Inga sp. (fruit tree, $\mathrm{N}$-fixing, and biomass accumulating species), and $S$. macrophylla (timber). These species constituted $45.2 \%$ of total shade tree species abundance. In regards to overall species composition, natural succession species constituted $22.8 \%$ of the total; the rest was composed of intentionally planted trees such as fruit, timber, medicinal, ornamental trees, or trees/palm trees that provide construction material. With regard to carbon accumulation, natural 
Fig. 5 The 15 most important shade tree species according to biomass in \%. The remaining 90 species constituted $39.9 \%$ of biomass (column not included in the graph)

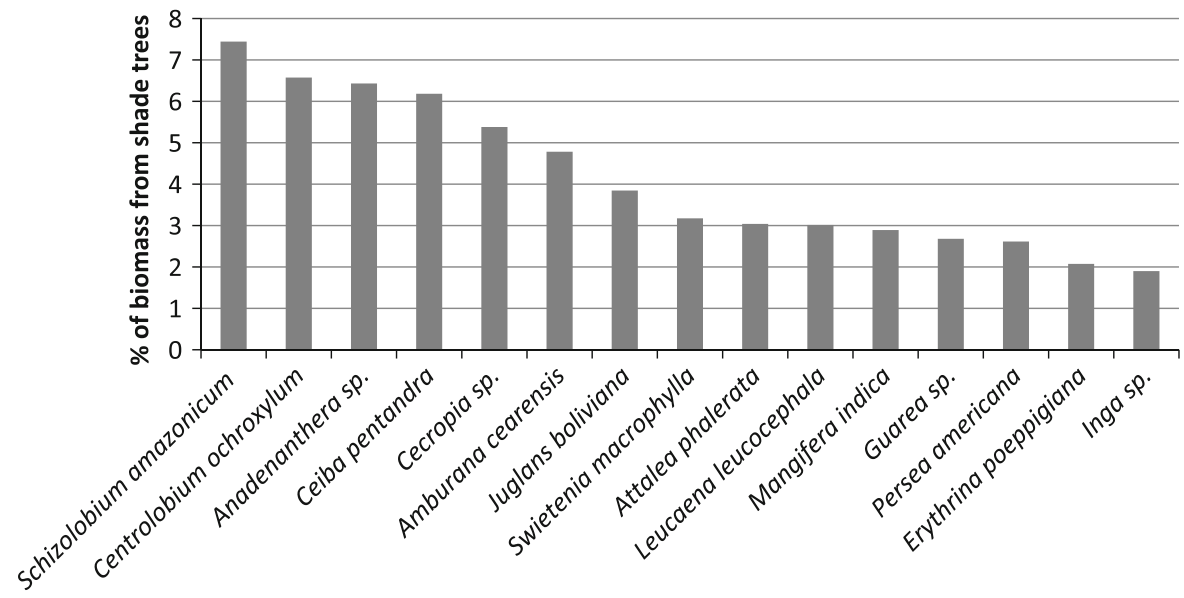

succession species constituted $25.9 \%$ of total shade tree biomass. In Fallow, $29.4 \%$ of tree biomass was composed of intentionally planted tree species (e.g., $L$. leucocephala). High-value timber tree species (Schizolobium amazonicum, C. ochroxylum, A. cearensis, and S. macrophylla) comprised $22.0 \%$ of total shade tree biomass. Figure 5 shows which species contributed most to shade tree biomass. The list of species abundance differed from the list of species contributing to biomass accumulation, since larger trees contributed most to biomass and carbon stocks. For instance, the numerous L. leucocephala stems (23.6\% of total shade tree species abundance) had small diameters and thus did not contribute much biomass (only $3.0 \%$ of total shade tree biomass).

The influence of organic certification on diversification of cocoa plots

Organic certification had a significant effect on shade tree diversity in cocoa plots $(P=0.0008837$, KruskalWallis rank-sum test); affiliation with a farmers' organization also had a significant effect on shade tree diversity $(P=0.0089$, Kruskal-Wallis rank-sum test $)$. The two variables (organic certification and affiliation with a farmers' organization) are associated, as 27 of 30 certified-organic farmers interviewed were affiliated with a farmers' organization, and 15 of 22 noncertified farmers interviewed were not affiliated with a farmers' organization. Organic cocoa producers mentioned that joining an El Ceibo cooperative to obtain organic certification offered the prospect of better prices for their product. All members of cooperatives had obtained organic certification or were in the process of transitioning to meet organic requirements. Nevertheless, farmers in the area need not be affiliated with an El Ceibo cooperative to obtain organic certification, since other organizations also facilitate organic certification in the region. The cocoa plots on such farms were also highly diversified, indicating that other organizations-not only El Ceibo cooperatives-can play a significant role in enhancing the diversity of crops and plants on farms (cf. Abruzzese et al. 2005). With regard to cocoa yields (which was part of another study on the same plots and three more Monos), SAFS displayed the highest annual yields (510 kg dry beans $\mathrm{ha}^{-1}$ ) and Mono the lowest (350 $\mathrm{kg} \mathrm{ha}^{-1}$ ), with AFS falling in between the two $\left(423 \mathrm{~kg} \mathrm{ha}^{-1}\right)$. AFS in general and SAFS in particular were more systematically managed than Mono, as indicated by a survey on management activities such as pruning and pest and plant-disease control (Jacobi et al. 2013).

The positive relationship between organic certification and shade tree diversity suggests that cocoa farmers who are affiliated with an El Ceibo cooperative or another organization that supports organic production are more likely to practice agroforestry. However, despite general awareness of the advantages of agroforestry among farmers practicing monoculture, the implementation of agroforestry systems does not appear to be expanding at present. Out of 52 farmers interviewed, 40 cited lack of knowledge of specific agricultural practices as a factor constraining their installation of agroforestry systems. At the same time, nearly all interviewees ( 48 of 52 farmers) displayed a high level of 
Table 6 Potentials and constraints of three different cocoa cultivation systems according to coca farmers $(n=52)$, number of citations in brackets; SAFS successional agroforestry system, AFS simple agroforestry system, Mono cocoa monoculture

\begin{tabular}{|c|c|c|}
\hline & Potentials & Constraints \\
\hline Mono & $\begin{array}{l}\text { High yields in the short } \\
\text { term (2) } \\
\text { Less labor input (5) }\end{array}$ & $\begin{array}{l}\text { More susceptible to } \\
\text { droughts (17) } \\
\text { More susceptible to pests } \\
\text { and diseases (15) } \\
\text { Soil erosion and } \\
\text { degradation (11) }\end{array}$ \\
\hline AFS & $\begin{array}{l}\text { Income from timber ( } 19, \\
\text { same for SAFS) } \\
\text { Shade is better for cocoa } \\
\text { trees and working } \\
\text { conditions (10, same for } \\
\text { SAFS) } \\
\text { Better water retention } \\
\text { capacity ( } 7 \text {, same for } \\
\text { SAFS) }\end{array}$ & $\begin{array}{l}\text { More labor input for } \\
\text { pruning of trees }(23 \text {, } \\
\text { same for SAFS) } \\
\text { Lack of equipment to } \\
\text { prune the trees ( } 9) \\
\text { Lower cocoa yields ( } 4 \text {, } \\
\text { same for SAFS) }\end{array}$ \\
\hline SAFS & $\begin{array}{l}\text { Diversified products (7) } \\
\text { Soil restoration (5) } \\
\text { Less susceptible to pests } \\
\text { and diseases (3) }\end{array}$ & $\begin{array}{l}\text { More labor input to } \\
\text { manage the different } \\
\text { crops }(12) \\
\text { Lack of knowledge and } \\
\text { extension services }(40)\end{array}$ \\
\hline
\end{tabular}

interest in extension services. Table 6 shows the most frequently mentioned potentials and constraints of the three different cocoa-cultivation systems.

\section{Discussion}

As the largest component of total biomass (see Fig. 3), shade trees are crucial to carbon stocks in the cocoa cultivation systems of Alto Beni. Of the cultivation systems analyzed in the current study, successional agroforestry systems displayed the most biomass and the highest total carbon stocks. Our results for total carbon stocks are comparable to the findings of other authors, e.g., Haeger (2012) who found stocks ranging from 76.1 to $109.1 \mathrm{Mg} \mathrm{ha}^{-1}$. Andrade et al. (2008) found $115.5 \mathrm{Mg} \mathrm{ha}^{-1}$ of carbon stocks in cocoa agroforestry-close to our findings-as well as SOC stocks ranging from 41.9 to $66.8 \mathrm{Mg} \mathrm{ha}^{-1}$. In comparison with Somarriba et al. (2008), our findings for total carbon stocks are medium for AFS and high for SAFS. We found considerable differences in carbon stocks and shade tree diversity between AFS and
SAFS - the latter system displaying different stories or strata that are filled with plants. Our finding of higher carbon stocks in SAFS compared with Fallow is also particularly interesting, as fallows reflect natural regeneration. One explanation for the lower carbon stocks found in Fallow could be that most fallow plots in the study area were 5-15 years old, which is not enough time for all stories to completely re-establish themselves naturally. Indeed, the fallow plots sampled in this study displayed less biomass and fewer total carbon stocks than SAFS, a cultivation system that is designed to mimic and accelerate the natural succession and structure of plant growth with multiple-use species (cf. Schulz et al. 1994). Ah horizon was deeper in SAFS and AFS than in Mono. This and the results for bulk density indicate that soils were less compacted in both successional and simple agroforestry systems. Our finding that SAFS had the highest amount of fine roots underscores the potential of this system for carbon sequestration in soils, as fine roots are considered a major contributor to soil organic matter (Nair et al. 2009a). We did not find evidence for significant differences in SOC stocks between the different cultivation systems. However, we cannot rule out that SOC was determined more by the initial conditions of plots than by the cultivation systems themselves, due to our lack of baseline data regarding the plots' SOC stocks prior to the current cultivation system (cf. FAO 2011). One other shortcoming of our research design was the difference in ages of the cultivation systems: Mono was the youngest system, and SAFS the oldest (Table 1). This occurred because various selection criteria had to be taken into account which made it impossible to find representative plots of the same age. Based on our finding that SAFS had the highest carbon stocks, we conclude that this cultivation system bears special potential in regards to climate change mitigation. According to interviews with cocoa farmers, two of the SAFS were begun in nutrient-poor soils, one in a pasture and the other in a cocoa monoculture (SAFS 2 and SAFS 3, Table 1). Vieira et al. (2009) have recommended combining the principles of forest restoration and successional agroforestry in order to accelerate restoration of soil fertility while improving farmers' food security. In this way, farmers can actively take charge of restoration efforts, and conflicts between the interests of soil restoration and agricultural production may be reduced (Vieira et al. 2009). 
In regards to tree diversity, SAFS plots displayed the highest Shannon index on average as well as the highest species richness of the cultivation systems assessed. Agrobiodiversity has been suggested as an important feature of agroecological systems in terms of their ability to adapt to climate change (e.g., Ifejika Speranza 2010; Henry et al. 2009; Niggli et al. 2007)_-SAFS may be considered promising in this context. The eastern foothills of the Andes belong to a hotspot of biodiversity (Myers et al. 2000); agroforestry systems in general and successional agroforestry systems in particular may serve as important buffer ecosystems here (cf. Rice and Greenberg 2000). The region of Alto Beni connects two national parks (Isibore Seguré and Madidi), and its agroforestry systems could play an important role on behalf of gene exchange. Selective logging has nearly eliminated certain tree species-such as S. macrophylla-that were frequently found in the region's primary forests. Several authors have argued that agroforestry provides an opportunity to protect such tree species in areas where overexploitation could lead to their extinction (Bhagwat et al. 2008; Orozco and Somarriba 2005). Indeed, S. macrophylla was frequently found in the agroforestry systems examined in the present study; farmers stated that they were planting timber trees for the future (Table 6). Many farmers claimed planting such trees would enable their children to study at a university. Indeed, authors have argued elsewhere that plantations of such high-value timber trees serve as a bank account for farming families (Tscharntke et al. 2011; Somarriba and Beer 2011). Similarly, ways should be found of incentivizing diversified agroforestry systems that provide various environmental benefits (Soto-Pinto et al. 2010). Organic certification may be one way of incentivizing agroforestry, but may not yet be sufficient because current certification standards-for example, European Union organic regulation (2008) — do not explicitly require agroforestry systems (e.g., IFOAM basic standards, IFOAM 2005). Thus, additional incentives are needed to foster cultivation of diverse-even successional-agroforestry systems, considering the high carbon stocks found in these systems and their potential to restore degraded soils (Vieira et al. 2009). When evaluating our sampling plots according to the criteria of two key coffee-certification mechanisms-Bird-Friendly and Rainforest Alliance (Philpott et al. 2007)—we found that all four SAFS plots would likely pass the "Bird-
Friendly" criteria, however the AFS plots would not due to insufficient shade stratification (three strata required, $40 \%$ shade cover, at least 10 tree species representing $1 \%$ or more of the total, $<60 \%$ comprised of Inga spp.). Nevertheless, according to our assessment, two of the four AFS plots would pass the Rainforest Alliance's ecological requirements for certification (two strata of shade, buffer zone, $40 \%$ shade cover, more than 12 tree species among others, Philpott et al. 2007). In particular, both agroforestry systems exceeded these certification organizations' species-richness requirements. At present, however, these particular certification mechanisms - and their benefits-remain unavailable to Alto Beni's cocoa producers.

When discussing the positive aspects of diversified agroforestry systems, it is important to note that these systems can never match all the benefits of natural forests. Since agroforestry systems cannot develop over decades or centuries, primary species are rare and pioneer and secondary species are abundant (Asare 2006; Rice and Greenberg 2000). Furthermore, these systems do not feature understory development as is found in natural forests. Thus, protected areas, in which natural processes may occur free of direct intervention, are and will remain indispensable (cf. Clough et al. 2011). Nevertheless, agroforestry provides a good means of sequestering carbon since it supports density and diversity-key elements of carbon sequestration (Somarriba et al. 2008). In addition, various studies have shown that agroforestry-even successional agroforestry-does not necessarily reduce cost effectiveness when compared with other management practices (e.g., Haggar et al. 2011; Ramirez and Somarriba 2000; Schulz et al. 1994).

Aside from fallow, the most common land use practice in the study area is slash-and-burn cultivation of annual crops for 1-2 years. Following slash-andburn preparation of a plot, perennial crops are planted or the plot is left fallow again for soil recovery. These techniques were also practiced in the plots sampled in the present study. However, there are other promising approaches in the study area, such as slash-and-mulch rather than slash-and-burn (for annual and perennial crops); widespread use of such techniques could significantly reduce greenhouse gas emissions from forest clearing and enhance organic material in soils. At present, however, techniques such as slash-andmulch are only practiced by a handful of farmers in the 
region-in particular those who receive support from a local organization-as these techniques require specific knowledge and labor-force availability. Our findings of a statistically significant relationship between farmers' membership in a cooperative/ organic certification and the (higher) number of shade tree species on their cocoa plots are consistent with the findings of Orozco and Somarriba (2005): Comparing tree density and diversity in the same region, these authors found that members of an organic cooperative had a higher number of shade trees on their cocoa plots and a greater commercial volume from their cocoa plantations than non-members. According to their study, members of organic cooperatives also receive more capacity building and technical assistance (Orozco and Somarriba 2005); this may provide one explanation for the higher cocoa yields we found in AFS and, in particular, SAFS compared with Mono, when we evaluated the same plots in a second study (Jacobi et al. 2013). Indeed, our data reinforce the idea that knowledge (in this case supported by cooperatives and other farmers' organizations) is crucial to successful implementation of cocoa agroforestry systems, particularly successional agroforestry systems (Table 6). This adds to a growing body of evidence including studies by Quelca et al. (2005), Orozco and Somarriba (2005), Ortiz and Somarriba (2005), and Miranda and Somarriba (2005). In the present study, cocoa producers who were affiliated with El Ceibo and underwent the organic-certification process were given access to shade tree seedlings as well as technical assistance in planting and management of such trees on their cocoa plots-incentives that clearly encourage the practice of agroforestry (Miranda and Somarriba 2005; Abruzzese et al. 2005).

\section{Conclusion}

Our study compared biomass and carbon stocks in cocoa cultivation systems of varying agroecological complexity. Biomass, carbon stocks, and species richness were highest in successional agroforestry systems-even when compared with fallow plots of a similar age. The results of the study indicate that diversified cocoa cultivation was enhanced by local farmers' organizations that promoted organic production. These organizations recommended diversification and supported it through courses and extension services emphasizing agroforestry. Certified-organic farms were found to have higher shade tree diversity. Indeed, farming families who maintained certifiedorganic plots were more likely to practice agroforestry, whereas non-certified farmers tended to practice full-sun monoculture (more common in the region). Based on this, we conclude that enhancement of carbon stocks and increased conservation of tree diversity are not likely to occur if individual farming families are left on their own; rather, these developments depend on increasing farmers' social capital, for example by bringing farming families together in cooperatives, or linking them to specific service providers such as certifying organizations. Further, we conclude that expanding access to organic certification increases the likelihood that cocoa farmers will implement diversified agroforestry. Nevertheless, the current organic-certification standards in place do not obligate cocoa farmers to transition from monoculture to agroforestry-based cultivation systems. Fostering a more widespread transition to agroforestry will require close collaboration between producers, their cooperatives, and certifying organizations. Finding ways of systematically supporting such collaboration is therefore key to fostering growth of more sustainable cocoa-growing systems.

Acknowledgments The authors would like to thank DITSL for financing a pre-study, the NCCR North-South program (Research Project 13) for supervision, AVINA Foundation for initial funding, KFPE Bern for financing an Echange Universitaire project with students from Bolivia, FiBL (Andreas Gattinger and Franco Weibel), the Planet Action program, DigitalGlobe, the Centre for Development and Environment (Anne Zimmermann, Anu Lannen), ECOTOP (Joachim Milz), the Facultad de Agronomía (Fanny Suxo) and Instituto de Ecología UMSA La Paz (Renate Seidel and Miguel Limachi), the foundation PIAF-El Ceibo (Vladimiro Mendieta and Ernesto Huanca), and two anonymous reviewers for their helpful comments.

\section{References}

Abruzzese R, Stoian D, Somarriba E (2005) Estrategias de vida de productores emprendedores y desarrollo empresarial rural en el Alto Beni, Bolivia. Agroforestería en las Américas 43-44:28-32

Andrade H, Ibrahim M (2003) Cómo monitorear el secuestro de carbono en los sistemas silvopastoriles? Agroforestería en las Américas 10:109-116

Andrade H, Segura M, Somarriba E, Villalobos M (2008) Valoración biofísica y financiera de la fijación de carbono por 
uso del suelo en fincas cacaoteras indígenas de Talamanca, Costa Rica. Agroforestería en las Américas 46:45-50

Asare R (2006) A review on cocoa agroforestry as a means for biodiversity conservation. Paper presented at the World Cocoa Foundation Partnership Conference, May 2006, Brussels

Bernaards C, Jennrich R (2012) GPArotation: GPA Factor Rotation. R package Version: 2012.3-1. Available from: http:// cran.r-project.org/web/packages/GPArotation. Accessed 15 Dec 2012

Bhagwat SA, Willis KJ, Birks HJ, Whittaker RJ (2008) Agroforestry: a refuge for tropical biodiversity? Trends Ecol Evol 23(5):261-267

Brown S (1997) Estimating biomass and biomass change of tropical forests. A primer. FAO Forestry Paper no. 134

Cairns MA, Brown S, Helmer EH, Baumgardner GA (1997) Root biomass allocation in the world's upland forests. Oecologia 111:1-11

Chave J, Andalo C, Brown S, Cairns MA, Chambers JQ, Eamus D, Fölster H, Fromard F, Higuchi N, Kira T, Lescure JP, Nelson BW, Ogawa H, Puig H, Riéra B, Yamakura T (2005) Tree allometry and improved estimation of carbon stocks and balance in tropical forests. Oecologia 145:87-99

Clough Y, Barkmann J, Juhrbandt J, Kessler M, Wanger TC, Anshary A, Buchori D, Cicuzza D, Darras K, Putra DD, Erasmi S, Pitopang R, Schmidt C, Schulze CH, Seidel D, Steffan-Dewenter I, Stenchly K, Vidal S, Weist M, Wielgoss AC, Tscharntke T (2011) Combining high biodiversity with high yields in tropical agroforests. PNAS 108(20):8311-8316

de Moraes JFL, Volkoff B, Cerri Carlos C, Bernoux M (1996) Soil properties under Amazon forest and changes due to pasture installation in Rondonia, Brazil. Geoderma 70:63-81

Don A, Schumacher J, Freibauer A (2011) Impact of tropical land-use change on soil organic carbon stocks-a metaanalysis. Glob Chang Biol 17:1658-1670

Elbers J (2002) Agrarkolonisation im Alto Beni Landschaftsund politisch-ökologische Entwicklungsforschung in einem Kolonisationsgebiet in den Tropen Boliviens. Dissertation, University of Duesseldorf

European Union organic regulation (2008) Verordnung (EG) Nr. 834/2007. http://www.bioaktuell.ch/de/bioregelwerk. html. Accessed 17 Jan 2013

FAO (2011) Organic agriculture and climate change mitigation-a report of the round table on organic agriculture and climate change, Rome

Gattinger A, Muller A, Haeni M, Skinner C, Fliessbach A, Buchmann N, Mäder P, Stolze M, Smit P, Scialabba N, Niggli U (2012) Enhanced top soil carbon stocks under organic farming. PNAS 109(44):18226-18231

Gelman A, Hill J, Yajima M (2012) Why we (usually) don't have to worry about multiple comparisons. J Res Educ Eff 5:189-211

Haeger A (2012) The effects of management and plant diversity on carbon storage in coffee agroforestry systems in Costa Rica. Agrofor Syst 86(2):159-174

Haggar J, Barrios M, Bolaños M, Merlo M, Moranga P, Munguia R, Ponce A, Romero S, Soto G, Staver C, de MF Virginio E (2011) Coffee agroecosystem performance under full sun, shade, conventional and organic management regimes in Central America. Agrofor Syst 82:285-301

Hairiah K, Sitompul SM, van Noordwijk M, Palm C (2001) Methods for sampling carbon stocks above and below ground. ASB Lecture Note 4B, Bogor

Henry M, Tittonell P, Manlay RJ, Bernoux M, Albrecht A, Vanlauwe B (2009) Biodiversity, carbon stocks and sequestration potential in aboveground biomass in smallholder farming systems of western Kenya. Agric Ecosyst Environ 129:238-252

ICRAF (2005) Tree diversity analysis - a manual and software for common statistical methods for ecological and biodiversity studies, Nairobi

ICRAF (2011) Wood Density Database. World Agroforestry Centre, http://wwwworldagroforestrycentreorg/sea/Products/ AFDbases/WD. Accessed 15 Nov 2011

Ifejika Speranza C (2010) Resilient adaptation to climate change in African agriculture. DIE Studies, Bonn

IFOAM (2005) The IFOAM Norms for organic production and processing. http://www.ifoam.org/about_ifoam/standards/ norms/norm_documents_library/Norms_ENG_V4_20090 113.pdf. Accessed 2 Dec 2011

IPCC (2003) Good practice guidance for land use, land-use change and forestry. IPCC National Greenhouse Gas Inventories Programme, Hayama

IPCC (2007) Climate Change 2007-synthesis report, Geneva

Jacobi J, Schneider M, Bottazzi P, Pillco M, Calizaya P, Rist S (2013) Agroecosystem resilience and farmers' perceptions of climate change impacts in cocoa farms in Alto Beni, Bolivia. Renw Agr Food Syst, online first

Koepke U (2008) Organic agriculture in the tropics and subtropics. Tropical series, 1, Köster, Berlin

Leifeld J, Fuhrer J (2010) Organic farming and soil carbon sequestration: what do we really know about the benefits? Ambio 39:585-599

Milz J (2010) Producción de Naranja (Cirtucus sinensis) en sistemas agroforestales sucesionales en Alto Beni, Bolivia-Estudio de caso. In: Beck S (ed) Biodiversidad y Ecología en Bolivia. Instituto de Ecología, Universidad Mayor de San Andrés (UMSA), La Paz, pp 324-340

Miranda M, Somarriba E (2005) Evaluación agronómica de las plantaciones de cacao injertado de productores de la Central de Cooperativas El Ceibo, Alto Beni, Bolivia. Agroforestería en las Américas 43-44:62-66

Mueller-Lindenlauf M (2009) Organic agriculture and carbon sequestration. Possibilities and constraints for the consideration of organic agriculture within carbon accounting systems. FAO, Rome

Myers N, Mittermeier RA, Mittermeyer CG, Fonseca GAB, Kent J (2000) Biodiversity hotspots for conservation priorities. Nature 403:853-858

Nair PKR (2011) Carbon sequestration studies in agroforestry systems: a reality-check. Agrofor Syst 86:1-11

Nair PKR, Kumar BM, Nair VD (2009a) Agroforestry as a strategy for carbon sequestration. J Plant Nutr Soil Sci 172:10-23

Nair PKR, Nair VD, Mohan KB, Haile S (2009b) Soil carbon sequestration in tropical agroforestry systems: a feasibility appraisal. Environ Sci Policy 12:1099-1111

Niggli U, Schmid H, Fliessbach A (2007) Organic farming and climate change. Briefing prepared by the Research Institute 
of Organic Agriculture FiBL, Frick, Switzerland, for the International Trade Centre ITC, Geneva

Noponen MRA, Edward-Jones G, Haggar JP, Soto G, Attarzadeh N, Healey JR (2012) Greenhouse gas emissions in coffee grown with differing input levels under conventional and organic management. Agric Ecosyst Environ 151:6-15

Orozco L, Somarriba E (2005) Árboles maderables en fincas de cacao orgánico del Alto Beni, Bolivia. Agroforestería en las Américas 34-44:46-53

Ortiz M, Somarriba E (2005) Sombra y especies arbóreas en cacaotales del Alto Beni, Bolivia. Agroforestería en las Américas 43-44:54-61

Patton MQ (2002) Qualitative evaluation and research methods. Sage, Beverly Hills

Pearson T, Walker S, Brown S (2005) Sourcebook for land use, land-use change and forestry projects. World Bank BioCarbon Fund and Winrock International, Washington

Philpott SM, Bichier P, Rice R, Greenberg R (2007) Fieldtesting ecological and economic benefits of coffee certification programs. Conserv Biol 21(4):975-985

Pinto W (2011) Clasificación orientada a objetos con imágenes de alta resolución para la determinación de la cobertura y uso del suelo en la región de Alto Beni, Bolivia, Master's thesis, Universidad Mayor de San Simón, Cochabamba

Quelca A, Bentes-Gama M, Pastrana A, Ochoa R (2005) Percepciones y valoración del sistema sucesional multiestrato de los productores cacaoteros del Alto Beni, Bolivia. Agroforestería en las Américas 43-44:77-80

R Development Core Team (2012) R: a language and environment for statistical computing. Vienna

Ramirez OA, Somarriba E (2000) Risk and returns of diversified cropping systems under nonnormal, cross-, and autocorrelated commodity price structures. J Agric Res Econ 25(2):653-668

Revelle W (2012) psych: procedures for psychological, psychometric, and personality research. $\mathrm{R}$ package Version 1.2.8. Available from: http://cran.r-project.org/web/ packages/psych. Accessed 15 Dec 2012

Rice R, Greenberg A (2000) Cacao cultivation and the conservation of biological diversity. Ambio 29(3):167-173

Roncal-García S, Soto-Pinto L, Castellanos-Albores J, RamírezMarcial N, de Jong B (2008) Sistemas Agroforestales y Almacenamiento de Carbono en Comunidades Indígenas de Chiapas. Mexico. Interciencia 33(3):7

Santos S, Miranda I, Tourinho M (2004) Biomass estimation of agroforestry systems of the Juba river floodplain in Cametá, Pará. Acta Amazonica 34(1):1-8

Schroth G, Sinclair FL (eds) (2003) Trees, crops and soil fertility: concepts and research methods. CABI, Bangor
Schulz J (2011) Imitating natural ecosystems through successional agroforestry for the regeneration of degraded lands - a case study of smallholder agriculture in northeastern Brazil. In: Smith J et al (eds) Agroforestry as a tool for landscape restoration. Nova Science Publishers, New York, pp 3-17

Schulz B, Becker B, Götsch E (1994) Indigenous knowledge in a "modern" sustainable agroforestry system-a case study from Brazil. Agrofor Syst 25:59-69

Scialabba NE-H, Mueller-Lindenlauf M (2010) Organic agriculture and climate change. Renew Agric Food Syst 25(2):158-169

Segura M, Kanninen M, Suárez D (2006) Allometric models for estimating aboveground biomass of shade trees and coffee bushes grown together. Agrofor Syst 68:143-150

Shannon CE, Weaver W (1949) The mathematical theory of communication. University of Illinois Press, Urbana

Somarriba E, Beer J (2011) Productivity of Theobroma cacao agroforestry systems with timber or legume service shade trees. Agrofor Syst 81:109-121

Somarriba E, Trujillo L (2005) El proyecto Modernización de la cacaocultura orgánica del Alto Beni, Bolivia. Agroforestería en las Américas 43-44:6-14

Somarriba E, Andrade HJ, Segura M, Villalobos M (2008) Cómo fijar carbono atmosférico, certificarlo y venderlo para complementar los ingresos de productores indígenas en Costa Rica? Agroforestería en las Américas 46:81-88

Soto-Pinto L, Anzueto M, Mendoza J, Jimenez Ferrer G, de Jong B (2010) Carbon sequestration through agroforestry in indigenous communities of Chiapas, Mexico. Agrofor Syst 78:39-51

Tscharntke T, Clough Y, Bhagwat SA, Buchori D, Faust H, Hertel D, Hölscher D, Juhrbandt J, Kessler M, Perfecto I, Scherber C, Schroth G, Veldkamp E, Wanger TC (2011) Multifunctional shade-tree management in tropical agroforestry landscapes-a review. J Appl Ecol 48:619-629

UNFCCC (2009) Approved simplified baseline and monitoring methodology for small-scale agroforestry-afforestation and reforestation project activities under the clean development mechanism. CDM-Executive Board ARAMS0004, Version 02

van Reeuwijk LP (2002) Procedures for soil analysis, 6th edn. Technical Paper 9, International Soil Reference and Information Centre, Wageningen

Vieira DLM, Holl KD, Peneireiro FM (2009) Agro-successional restoration as a strategy to facilitate tropical forest recovery. Restor Ecol 17(4):451-459

Yana W, Weinert H (2001) Técnicas de sistemas agroforestales multiestrato-manual práctico. PIAF-El Ceibo, La Paz 